\title{
Thermal Stability of Austempered Ductile Iron Evaluated in a Temperature Range of 20-300K
}

\author{
Dawid MYSZKA ${ }^{1 *}$, Maciej KOWALCZYK ${ }^{2}$, Maciej SPYCHALSKI ${ }^{2}$, \\ Andrzej WIECZOREK ${ }^{3}$
}

\author{
${ }^{1}$ Warsaw University of Technology, Institute of Manufacturing Technology, ul. Narbutta 85, Warsaw, Poland \\ ${ }^{2}$ Warsaw University of Technology, Faculty of Materials Engineering, ul. Wołoska 141, Warsaw, Poland, \\ ${ }^{3}$ Silesian University of Technology, Faculty of Mining and Geology, ul. Akademicka 2, 44-100 Gliwice, Poland
}

cross $^{\text {ref }}$ http://dx.doi.org/10.5755/j01.ms.22.1.7505

Received 01 July 2014; accepted 07 February 2015

\begin{abstract}
The aim of this article was to determine through changes in magnetic properties the stability of the austempered ductile iron (ADI) microstructure during temperature changes in a range of 20-300 K. The measurements were taken in a vibrating sample magnetometer (VSM) using Fe27Ni2TiMoAlNb austenitic stainless steel and four types of austempered ductile iron obtained under various heat treatment conditions. The plotted curves showing changes in the magnetisation degree as a function of temperature had a number of characteristic points illustrating changes taking place in the microstructure. For each of the materials examined, the martensite start temperature Ms and the temperature range within which the martensitic transformation takes place were identified.

Keywords: austempered ductile iron, cryogenic treatment, thermal stability, martensitic transformation.
\end{abstract}

\section{INTRODUCTION}

Austempered ductile iron is a material classified according to the European Standard, which describes a very broad range of its properties. The most representative of these are the commonly quoted good ductility, exceeding $10 \%$, with tensile strength higher than $900 \mathrm{MPa}$ or very high tensile strength, recorded at $1600 \mathrm{MPa}$ for a different grade of ADI. Austempered ductile iron, however, features several other properties, which predestine it for application to a diversity of structural components. Those properties, which are best known, are: capability of vibration damping, $10 \%$ lower density in comparison with steel, good machinability prior to heat treatment, propensity for strengthening of casting surfaces during burnishing or shot peening, etc $[1-5]$.

The reason for such good properties of austempered ductile iron is the appropriately carried out heat treatment cycle, comprising austenitization and quenching with isothermal transformation. Both these processes are extremely important from the point of view of microstructural transformations and, by the same token, properties of ADI. Austenitization determines the content of carbon in austenite and its homogenization, while the isothermal transformation, taking place after quenching from the austenitizing temperature, determines the morphology of the mixture of ferrite and austenite (ausferrite), observed at ambient temperature and finally responsible for the properties of ADI. Such a description of heat treatment of ductile iron seems to be very simple to carry out and leads to the obtaining of proper effects. As investigations reveal, it is not always possible to fulfill minimum criteria described by the specification [1].

\footnotetext{
* Corresponding author. Tel.: +48 2223484 62; fax: +48 228499797. Email address: myszkadawid@wp.pl (D. Myszka)
}

Control of the heat treatment process, as follows from several investigations, boils down mainly to determining the appropriate amount of austenite in the matrix of the required grade of austempered ductile iron $[6,7]$. In the light of new investigations carried out by the authors of this article, the above fact may be restated in a manner that is more precise. Why this is needed? The first reason for this is the question about the non-uniformity of mechanical properties of ADI which reveals itself even with a constant amount of austenite in the ausferritic matrix. The second reason may be the lack of unequivocal justification of nonuniformity of austenite surrounded by platelets of ferrite at ambient temperature. Such austenite will occur in at least two forms: stable austenite (approx. > $1.6 \% \mathrm{C}$ ), metastable austenite (approx. $<1.6 \% \mathrm{C}$ ). Each one of these austenite will feature a different characteristic and its proportion will be able to determine the final properties of the entire casting.

Quantitative determination of metastable austenite content in general is not an easy task. In ADI, besides this type of austenite, there are several other phases, such as graphite, ferrite and stable austenite. Their presence makes the detectability of metastable austenite by conventional methods such as X-ray diffraction or image analysis much more difficult [8]. Therefore, of great importance are methods based on the analysis of phase transformations or changes recorded in magnetic properties during the impact of temperature. The assumptions made above can be used in an analysis of transformation in microstructure, especially as regards austenite in austempered ductile iron generally considered to be the phase thermally and mechanically unstable [9-13].

As part of the study, tests were conducted in a vibrating sample magnetometer (VSM) on samples of austempered ductile iron obtained under various conditions of heat treatment. As a result of these studies, on the plotted curves, numerous characteristic points related with changes in the 
ductile iron microstructure following changes in the temperature of the examined material in a range of approximately $20-300 \mathrm{~K}$ were observed.

\section{EXPERIMENTAL DETAILS}

Samples in the form of $\varnothing 3 \mathrm{~mm} \times 3 \mathrm{~mm}$ rods were made from the Fe27Ni2TiMoAlNb steel and ductile iron of the chemical composition: $3.4 \% \mathrm{C}, 2.8 \% \mathrm{Si}, 0.28 \% \mathrm{Mn}$, $0.27 \% \mathrm{Mo}$ and $0.72 \% \mathrm{Cu}$. The heat treatment of ductile iron was conducted at the Institute for Manufacturing Technology WUT using an FPM400 chamber furnace and fluidised bed based on $\mathrm{SiC}$ with the grain size of approximately $100 \mu \mathrm{m}$. The heat treatment process consisted in austenitising ductile iron castings at $1173 \mathrm{~K}$ for 120 minutes and then austempering at $643 \mathrm{~K}$ and $673 \mathrm{~K}$ for 30 and 180 minutes. The successive samples of austempered ductile iron were designated as ADI 643_030, ADI 643_180, ADI 673_030 and ADI 673_180.

To determine changes in the content of ferromagnetic phases in the austempered ductile iron, samples were freezed and simultaneously their magnetic properties were measured. The whole process was carried out in a vibrating sample magnetometer (VSM), which is part of the physical properties measurement system (PPMS) from Quantum Design. This device allows measurement of the magnetisation value $M$ [emu - elementary magnetic unit per gram] of the examined material subjected to a preset magnetic field $H[\mathrm{Oe}]$ in any arbitrarily selected temperature regime from the range of $2-1000 \mathrm{~K}$. The magnetic field is generated by current flowing in a coil of superconducting material. The temperature is achieved through a subtle game of vapours of the evaporating helium and heating elements surrounding the sample. Samples of Fe27Ni2TiMoAlNb steel and of four types of austempered ductile iron weighing approximately $230 \mathrm{mg}$ each were used. The measurements on four samples were taken in a 100 Oe magnetic field and in a temperature range of $300 \div 20 \div 300 \mathrm{~K}$. The obtained results showing a relationship between the magnetisation and temperature allowed the qualitative and quantitative determination of changes occurring in the tested material during cooling.

The tests of nanoindentation of ADI samples after cryogenic treatment were made on the Hysitron Ti 950 TriboIndneter. Trapezoid course of the load was used for the tests and the device was operated in force feedbackcontrol mode. Maximum load of $2 \mathrm{mN}$ was used. In the hardness measurements 400 indentations were made in a square grid of 20 impressions per row and 20 impressions per column. Minimum distance between the impressions was $2 \mu \mathrm{m}$.

\section{RESULTS AND DISCUSSION}

The first measurement was taken to capture changes in the sample of Fe27Ni2TiMoAlNb austenitic steel showing the TRIP (TRansformation Induced Plasticity) effect (Fig. 1). In this way, a complete transformation of fully austenitic microstructure into martensite (paramagnetic phase into ferromagnetic phase) was documented and the Martensite start temperature (Ms) was established at about $180 \mathrm{~K}$. The next series of tests was performed on four different types of ductile iron subjected to different heat treatment processes. Compared with the graph in Fig. 1, the graph in Fig. 2 shows that also the paramagnetic phase has been transformed into a ferromagnetic one. This effect occurs on a smaller scale than it does in the case of austenitic steels, but it assumes a similar form. This may mean a transformation of metastable austenite present in the austempered ductile iron into martensite below the $M \mathrm{~s}$ temperature. The measurement taken again on one of the ductile iron samples previously frozen gave no information about other transformations, thus indicating microstructure stabilisation.

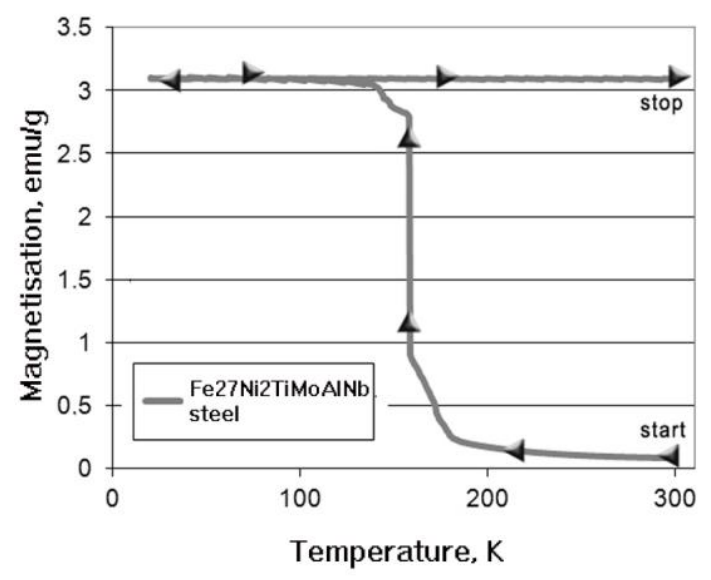

Fig. 1. Diagram illustrating changes in magnetisation as a function of cooling and heating the austenitic steel sample in a temperature range of $300 \div 20 \div 300 \mathrm{~K}$

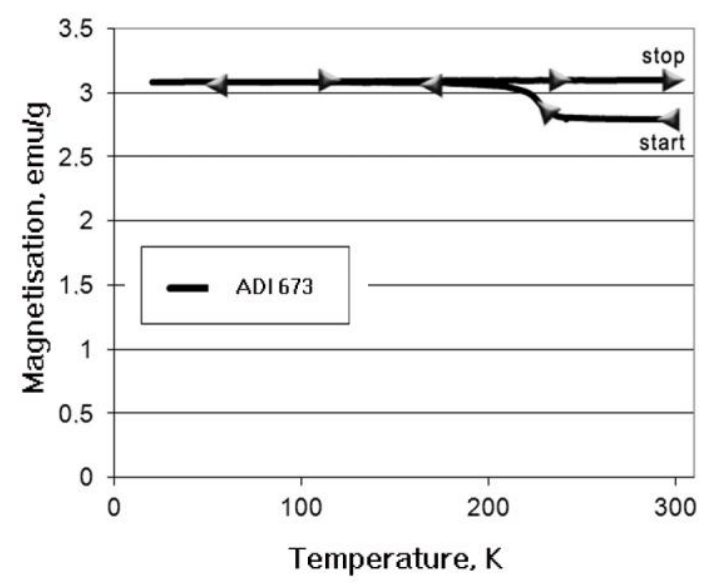

Fig. 2. Diagram illustrating changes in magnetisation as a function of cooling and heating the ADI 673_030 austempered ductile iron sample

The most interesting in this analysis are the graphs shown in Fig. 3. With great accuracy they reflect changes in the magnetic properties of ductile iron subjected to a short- and long-term treatment of isothermal transformation at a preset temperature.

They indicate that:

- the Ms temperature decreases with the progressing time of the transformation (Table 1);

- the course of the austenite to martensite transformation is similar for the same temperature of isothermal quenching regardless of its duration; 
- higher temperature of the transformation and its longer duration promote more rapid transformation of austenite to martensite;

- less violent reaction may indicate the heterogeneity of austenite, which means that the transformation starts from the least stable austenite.

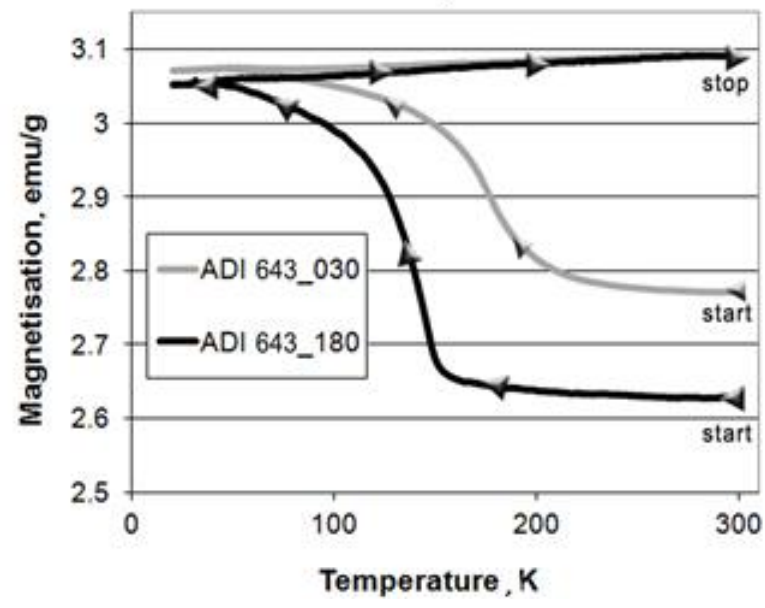

a

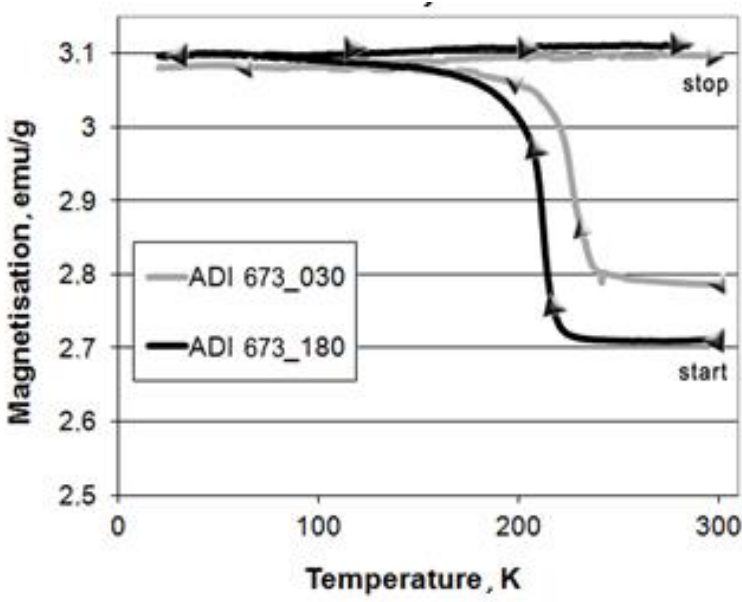

b

Fig. 3. Diagram illustrating changes in magnetisation as a function of cooling and heating within the temperature range of $300-20-300 \mathrm{~K}$ the samples of austempered ductile iron austempered at: $\mathrm{a}-643 \mathrm{~K}, \mathrm{~b}-673 \mathrm{~K}$ for the time of 30 and 180 minutes

Table 1. Estimated Ms and Mf temperature in austempered ductile iron and austenitic steel

\begin{tabular}{|l|c|c|}
\hline Sample designation & $\begin{array}{c}\text { Estimated } \mathrm{M}_{\mathrm{s}} \\
\text { temperature, } \mathrm{K}\end{array}$ & $\begin{array}{c}\text { Estimated } \mathrm{M}_{\mathrm{f}} \\
\text { temperature, } \mathrm{K}\end{array}$ \\
\hline Fe27Ni2TiMoAlNb & 180 & 140 \\
\hline ADI 673_030 & 240 & 135 \\
\hline ADI 673_180 & 220 & 100 \\
\hline ADI 643_030 & 200 & 85 \\
\hline ADI 643_180 & 150 & 50 \\
\hline
\end{tabular}

Austenite in austempered ductile iron is the phase having its own specific characteristics depending on various factors. Those most often cited and investigated are related with the effect of chemical composition and heat treatment parameters [1-3, 14-33], which could also be found in the above analysis. One can, however, accept some generalisations covering the whole family of austempered ductile irons. These generalisations can be reduced to the following statements:

- the microstructure of austempered ductile iron contains austenite, whose Ms temperature will be lower than $273 \mathrm{~K}\left(0^{\circ} \mathrm{C}\right)$,

- this austenite is not homogeneous as indicated large temperature range between $\mathrm{Ms}$ and $\mathrm{Mf}$,

- the transformation of austenite into martensite during cryogenic of austempered ductile iron can be effectively analysed by magnetic methods.

It is difficult to confirm the presence of martensite formed by freezing of the ausferritic matrix of ductile iron, as the microstructure before and after this process remains nearly unchanged (Fig. 4 and Fig. 5).

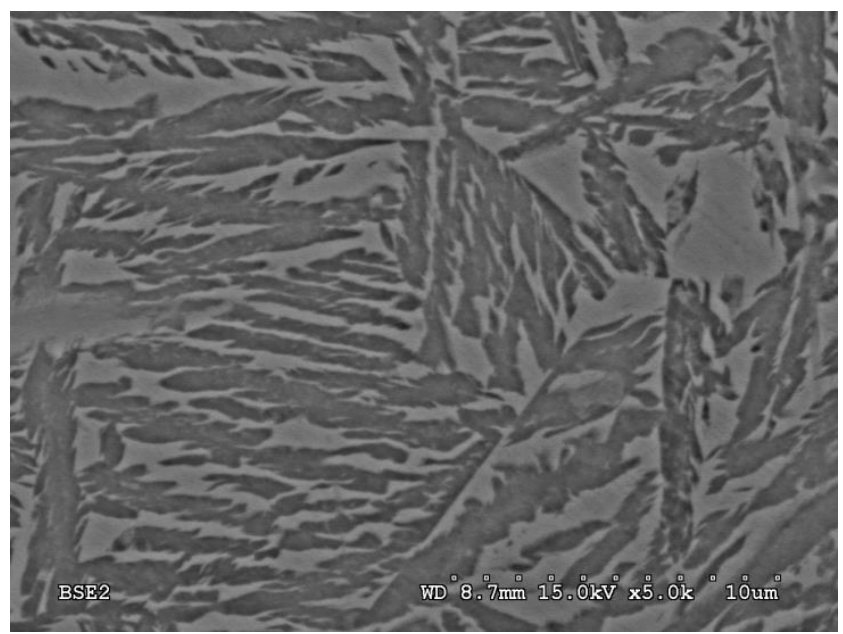

Fig. 4. Microstructure of matrix of austempered ductile iron; SEM

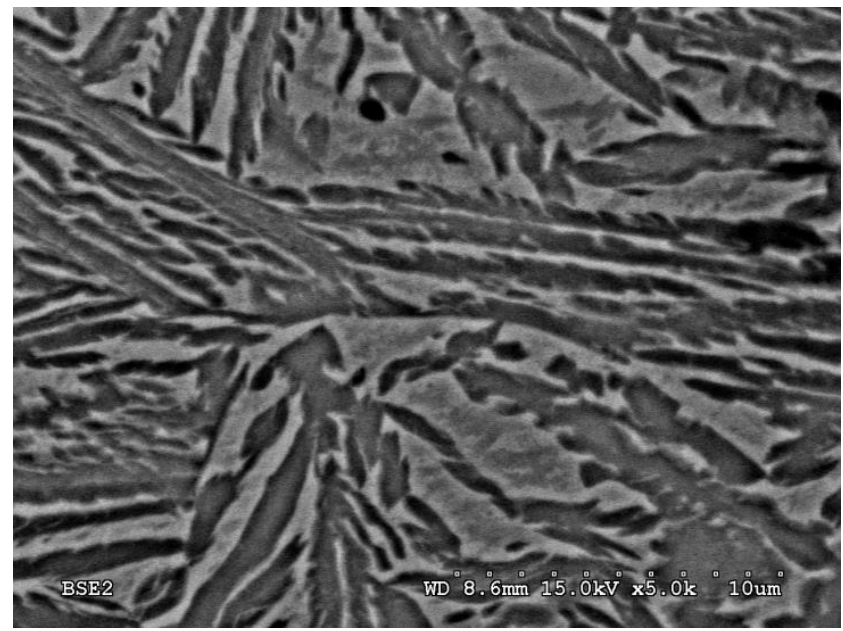

Fig. 5. Microstructure of austempered ductile iron after cryogenic treatment; SEM

The presence of martensite in the structure can be confirmed by nanohardness testing (Fig. 6). The study has allowed finding that in the large fields of block austenite, despite the absence of the visible fields of martensite, there is a marked increase in hardness compared to the hardness of ferrite plates or carbon-saturated austenite fields in the vicinity of these plates (Fig. 7). The presence of martensite can be confirmed also by special etching techniques that reveal its presence after freezing in the fields of primary block austenite (Fig. 8). 


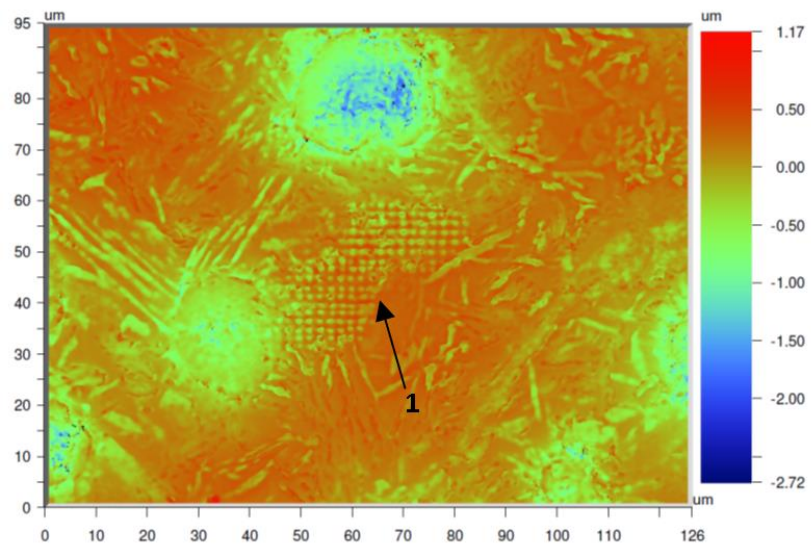

Fig. 6. Patern of nanoindentation (1) in the matrix of austempered ductile iron

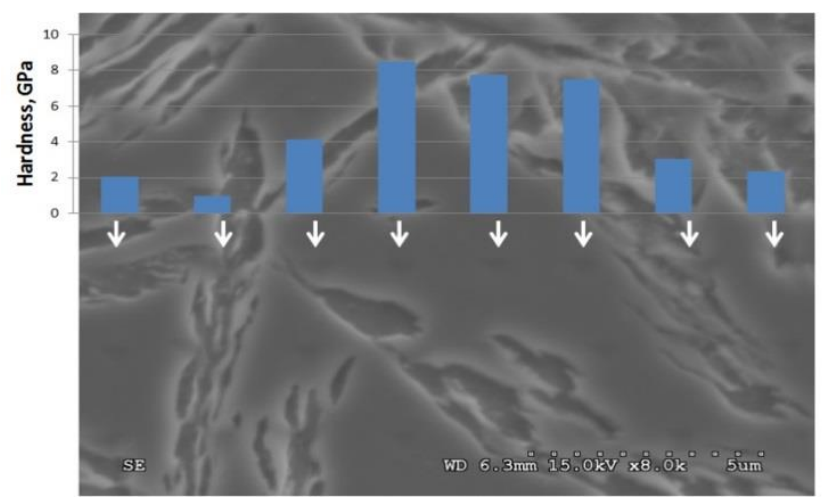

Fig. 7. Values of nanohardness in austenite and ferrite plates in microstructure of austemered ductile iron; SEM

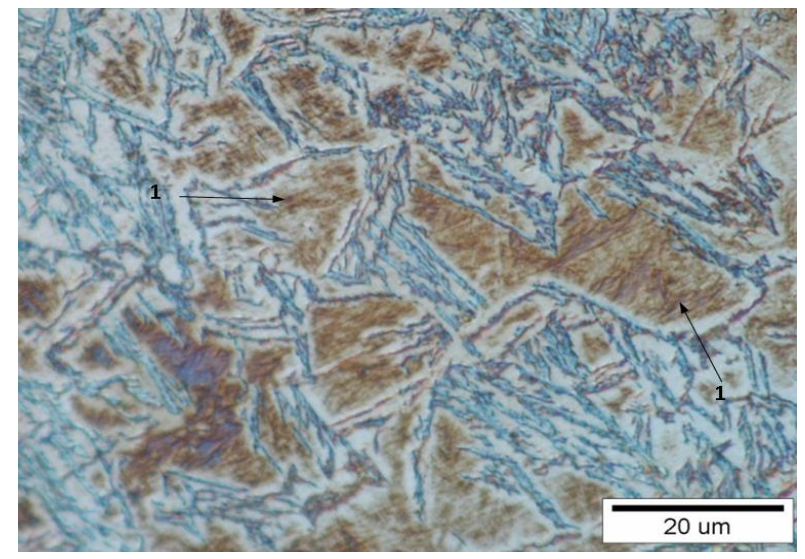

Fig. 8. Microstructure of austempered ductile iron matrix after cryogenic treatment, 1 - martensite; special etching; LM

\section{CONCLUSIONS}

As a result of studies, on the recorded curves of magnetisation versus temperature, numerous characteristic points related with changes in the microstructure induced by changes in the temperature of the material were observed. The main achievement of the studies was identification of the Ms and Mf temperature in different types of the austempered ductile iron (including a comparison of this material with the austenitic steel undergoing a TRIP effect) and proposals for the reconstruction of its microstructure under the effect of temperature kept in a range of $20-300 \mathrm{~K}$. This is of particular importance for understanding the phenomena occurring in the microstructure of ADI, and in practice the influence of low temperature on the parts of machines working in temperatures below $273 \mathrm{~K}$.

\section{REFERENCES}

1. Nofal, A. Advances in the Metallurgy and Applications of ADI Journal of Metallurgical Engineering 2 (1) 2013: pp. $1-18$.

2. Roedter, H. ADI - Austempered Ductile Iron, Biuletin Metals Minerals 22004.

3. SECTION IV. AUSTEMPERED DUCTILE IRON, www.ductile.org.

4. Guzik, E. Refining Processes of Iron Cast - Selected Issues, Archives of Foundry Engineering, Katowice 2001.

5. Hayrynen, K.H., Keough, J.R. Austempered Ductile IronThe State of the Industry in 2003. Proceedings of Keith D. Millis Symposium, Livonia 2003.

6. Ahmadabadi, M.N. Bainitic Transformations in Austempered Ductile Iron with Reference to Untransformed Austenite Volume Phenomenon Metallurgical and Materials Transactions A 28A 1997: pp. 2159-2162.

7. Chang, L.C. An Analysis of Retained Austenite in Austempered Ductile Iron Metallurgical and Materials Transactions A 34A 2003: pp. 211-217.

8. Myszka, D., Giętka, T. Comparing the Possibilities of Austenite Content Determination in Austempered Suctile Iron Archives of Foundry Engineering 11 (3) 2011: pp. 135-141.

9. Aranzabal, J., Guitierrez, I., Rodriguez-Ibabe, J.M., Urcola, J.J. Influence of the Amount and Morphology of Retained Austenite on The Mechanical Properties of an Austempered Ductile Iron Metallurgical and Materials Transactions A 28A 1997: pp. 1143-1156.

10. Myszka, D. Austenite-Martensite Trasformation in Austempered Ductile Iron Archives of Metallurgy and Materials 52 2007: pp. $475-480$.

11. Srinivasmurthy, D., Prasad, R.P. Formation of StrainInduced Martensie in Austempered Ductile Iron Journal of Materials Science 43 2008: pp. 357-367.

12. Garin, J.L., Mannheim, R.L. Strain-Induced Martensite in ADI Alloys Journal of Materials Processing Technology 143-144 2003: pp. 347-351. http://dx.doi.org/10.1016/s0924-0136(03)00452-7

13. Kumari, U.R., Prasad, R.P. Study of Wear Behaviour of Austempered Ductile Iron Journal of Materials Science 44 2009: pp. $1082-1093$.

14. Kapturkiewicz, W., Fraś, E., Burbelko, A.A. Modeling of Austenitizing Process in Cast Iron With Pearlitic Matrix Materials Science and Engineering: A 413-414 2005: pp. 352-357.

15. Biernacki, R., Kozlowski, J., Myszka, D., Perzyk, M. Prediction of Properties of ADI Assisted By Artificial Neural Network Materials Science (Medziagotyra) 12 (1) 2006: pp. $11-15$.

16. Ymanaca, M., Tamura, R., Inoue, K., Narita, Y. Bending Fatigue Strenght of Austempered Ductile Iron Spur Sears Journal of Advanced Mechanical Design Systems and Manufacturing 3 (3) 2009: pp. 203-211. http://dx.doi.org/10.1299/jamdsm.3.203

17. Voigt, R.C., Loper, C.R. Austempered Ductile Iron-Process Control and Quality Assurance Journal of Heat Treating 3 (4) 1984: pp. 291-309. 
18. Chang, L.C. An Analysis of Retained Austenite in Austempered Ductile Iron Metallurgical and Materials Transactions A 34A 2003: pp. 211-217.

19. Darwish, N., Elliot, R. Austempering of Low Manganese Ductile Irons Part 1. Processing window Material Science and Technology 9 (7) 1993: pp. 572-586. http://dx.doi.org/10.1179/mst.1993.9.7.572

20. Kovacs, B. V. On the Terminology and Structure of ADI AFS Transactions 1994: pp. 417-420.

21. Bayati, H., Elliot, R. The Concept of an Austempered Heat Treatment Processing Window International Journal of Cast Metals Research 11 1999: pp. 413-417.

22. Cinceros, G., Perez, L., Campos, C., Valdes, C. The Role of $\mathrm{Cu}, \mathrm{Mo}$ and $\mathrm{Ni}$ on the Kinetics of the Bainitic Reaction During the Austempering of Ductile Irons International Journal of Cast Metals Research 11 1999: pp. 425-430.

23. Rouns, T. N., Rundman, K. B., Moore, D. M. On The Structure and Properties of Austempered Ductile Cast Iron AFS Transactions 92 1984: pp. 815-840.

24. Trudel, A., Gangne, M. Effect of Composition and Heat Treatment Parameters on The Characteristics of Austmpered Ductile Iron Canadian Metallurgical Quarterly 36 (5) 1997: pp. 289-298.

25. Rundman, K.B., Parolini, J.R., Moore, D.J. Relationship Between Tensile Properties and Matrix Microstructure in Austempered Gray Iron AFS Transactions 145 (05) 2005: pp. $1-15$.

26. Jianghuai, Y., Putatunda, S.K. Influence of a Novel TwoStep Austempering Process on The Strain-Hardening
Behaviour of Austempered Ductile Cast Iron (ADI) Materials Science and Engineering A 382 2004: pp. $265-279$. http://dx.doi.org/10.1016/j.msea.2004.04.076

27. Tybulczuk, J., Kowalski, A. Characteristic of ADI with additions of $1.5 \% \mathrm{Ni}$ and $0.8 \% \mathrm{Cu}$ Foundry Research

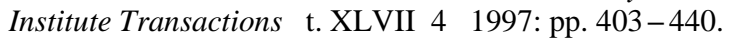

28. Campos-Cambranis, R.E., Navarez-Hernandez, L., Ciseros-Guerrero, M.M., Perez-Lopez, M. Effect of Initial Microstructure on The Activation Energy of Second Stage During Austempering of Ductile Iron Scripta Materialia 38 (8) 1998: pp. $1281-1287$.

29. Rivera, G., Boeri, R., Sikora, J. Influence of the Inoculation Process, The Chemical Composition and the Cooling Rate, on The Solidification Macro and Microstructure of Ductile Iron International Journal of Cast Metals Research $16(1-3)$ 2003: pp. 23-28.

30. Myszka, D., Cybula, L., Wieczorek, A. Influence of Heat Treatment Conditions on Microstructure and Mechanical Properties of Austempered Ductile Iron After Dynamic Deformation Test Archives of Metallurgy and Materials 59 (3) 2014: pp. 1181-1189.

31. Myszka, D., Skolek, E., Wieczorek, A. Manufacture of Toothed Elements in Nanoausferritic Ductile Iron Archives of Metallurgy and Materials 59 (3) 2014: pp. 1227-1231.

32. Myszka, D., Wieczorek, A. An Assessment of the Applicability of Austempered Ductile Iron Containing Mo And Ni For Mining Machines Parts Archives of Metallurgy and Materials 58 (3) 2013: pp. 967-970. 